\title{
Hymn dla nerdów. Stranger Things, czyli popkulturowe lata 80. w pigułce
}

\section{Abstrakt:}

Artykuł poświęcony jest analizie serialu Stranger Things (2016- ) w kontekście licznych aluzji i odwołań do utworów literackich, filmowych czy muzycznych z lat 80 . XX wieku. Autor tekstu dowodzi, że serial braci Dufferów wpisuje się w obecne we współczesnej kulturze popularnej zjawisko retromanii. Nostalgiczna tęsknota za adolescencją oraz retroobiektami (takimi jak walkman, winyle, kasety magnetofonowe) wynika m.in. z przyspieszonego tempa zmian zachodzących w dzisiejszym świecie. Dawne nośniki muzyczne oraz filmowe przeżywają obecnie renesans, gdyż poszukujemy rzeczy trwałych w przeszłości. Stranger Things to niemalże przewodnik po latach 80., jako że braci Dufferów fascynuje nie tylko twórczość m.in. Stephena Kinga, Stevena Spielberga, Wesa Cravena, lecz także ówczesne sposoby spędzania wolnego czasu z przyjaciółmi. Świat w Stranger Things jest ponadto dziwny, bizarny, trudny do zdefiniowania - może to jeden z powodów, dla których ta historia jest tak angażująca.

\section{Słowa kluczowe:}

adolescencja, lata 80. XX wieku, Matt Duffer, nostalgia, retromania, Ross Duffer, serial młodzieżowy, Stephen King, Steven Spielberg, Stranger Things

\section{Anthem for Nerds: Stranger Things, or the Pop Culture 1980s in a Nutshell}

\section{Abstract:}

This article is devoted to the analysis of the TV series Stranger Things (2016- ) in the context of numerous allusions and references to literary, film, and musical works from the 1980s. The author of the paper shows that the Duffer brothers' series is

* Dariusz Piechota - dr, pracuje na Wydziale Filologicznym Uniwersytetu w Białymstoku. Członek Laboratorium Animal Studies - Trzecia Kultura, nauczyciel w Zespole Szkół nr 3 w Puławach. Jego zainteresowania badawcze obejmują literaturę drugiej połowy XIX wieku, ekokrytykę, animal studies, najnowszą prozę popularną. Kontakt: darekpiechota@o2.pl. 
part of the retromania phenomenon present in contemporary popular culture. The nostalgic longing for adolescence and retro objects (such as walkmans, vinyls, cassettes) results, among others, from the accelerated pace of changes taking place in today's world. Old-time music and film media are currently experiencing a renaissance, as we are looking for things that were permanent in the past. Stranger Things is almost like a guide to the 1980s, as the Duffer brothers are fascinated not only by the works of, inter alia, Stephen King, Steven Spielberg, and Wes Craven, but also by the then ways of spending free time with friends. The world in Stranger Things is also strange, bizarre, difficult to define, which may be one of the reasons why the story is so engaging.

Key words:

adolescence, 1980s, Matt Duffer, nostalgia, retromania, Ross Duffer, young adult television series, Stephen King, Steven Spielberg, Stranger Things

C lobalny sukces serialu Stranger Things (Duffer, Duffer, 2016- ) wpisuje $\checkmark$ się w dominujące w kulturze popularnej zjawisko retromanii, obejmujące współczesny film, muzykę oraz sztukę (Reynolds, 2011/2018, s. 7). Obsesję na punkcie przeszłości potwierdzają reaktywacje kultowych zespołów z lat 80. i 90. $\mathrm{XX}$ wieku, reedycje ich albumów, koncertowe wydania płyt. Do minionych dekad odwołują się też twórcy telewizyjni: nakręcono nową wersję Dynastii (Shapiro, Shapiro, 1981-1989) - serial pod tym samym tytułem (Patrick, Schwartz, Savage, 2017- ), Beverly Hills, 90210 (Star, 1990-2000) doczekało się remake’u pt. BH90210 (Garth, Spelling, Chessler, Alberghini, 2019), David Lynch nakręcił trzeci sezon Miasteczka Twin Peaks (Frost, Lynch, 2017), a protagonista thrillera Milczenie owiec (Demme, 1991) został - w innym środowisku narracyjnym - głównym bohaterem serialu Hannibal (Fuller, 2013-2015). W telewizji coraz częściej pojawiają się programy typu Kochamy lata... (BBC) czy To był rok... (TVP1), w których z nostalgią wspomina się nie tylko popularnych artystów minionych dekad (Reynolds, 2011/2018, s. 10-11), lecz także przedmioty mające obecnie status kultowy (takie jak walkman, discman). W drugiej dekadzie XXI wieku obserwujemy też - w tekstach kultury i w życiu codziennym - rosnące zainteresowanie winylami, kasetami magnetofonowymi i VHS, a także dawnymi grami planszowymi oraz elektronicznymi (w Polsce np. radzieckimi).

Na fenomen współczesnych powrotów do przeszłości warto spojrzeć z perspektywy socjologicznej. Wraz z przejściem z epoki analogowej do cyfrowej zmieniła się sfera konsumpcji. Przyspieszone tempo zmian cywilizacyjnych zachodzących w nowym stuleciu - zwłaszcza w świecie zachodnim - sprawiło, że nasza egzystencja stała się ulotna. $Z$ jednej strony, nowoczesna technologia 
pozwala nam na magazynowanie, katalogowanie i udostępnianie artefaktów kojarzących się z epoką analogową. Z drugiej zaś - tęsknimy za materialnością tamtych przedmiotów, które we współczesnym świecie zostały „upłynnione". Piosenki oraz filmy uległy kompresji, zamieniono je w pliki, nazwane przez Simona Reynoldsa (2011/2018) „dźwiękowym ekwiwalentem fast fooda” (s. 12); przekształcone zostały w strumień danych, swobodnie przenoszonych i kopiowanych z urządzenia na urządzenie. Niepokój dotyczący przyszłości jest potęgowany przez zjawisko prekariatu - nowej grupy społecznej, do której należą osoby pozbawione stałego zatrudnienia, a co z tego wynika możliwości korzystania $\mathrm{z}$ funduszu socjalnego, uczestniczenia w szkoleniach oraz rozwoju zawodowego (Kryńska, 2017, s. 13-26). Często też wykonują one pracę poniżej posiadanego wykształcenia, co jest źródłem rosnącej frustracji. Prekariat stał się czytelnym dowodem na to, że znaczenie pracy ludzkiej znacznie się obniżyło, ale przede wszystkim wyeksponował problem biedy oraz rozwarstwienia społecznego. Rozczarowanie epoką cyfrową i towarzyszący jej nieustanny strumień danych wraz z wypaleniem zawodowym oraz utratą kontroli nad własnym życiem przyczyniły się do poszukiwania alternatywnej rzeczywistości, upatrywanej w przeszłości.

Warto podkreślić, że powroty do minionych dekad w najnowszej popkulturze wiążą się także ze zjawiskiem kulturowego remiksu, charakterystycznego dla utworów postmodernistycznych. Liczne remaki, sequele, prequele, crossovery, covery, revivale świadczą o nieustannie dokonującym się recyklingu. Reaktywacje te przyjmują formę intertekstualnych gier, dostarczających materiału do kolaży, powtórzeń typowych dla konstrukcji patchworkowej. Często budzą skojarzenia $\mathrm{z}$ mashupem, miksującym utwory z różnych obiegów kultury (Nacher, 2011). Zabieg ten nie tylko „ożywia” relikty przeszłości, lecz także wywołuje „epidemię" wspomnień, potęgowaną przez rynek konsumencki - wzbudzający tęsknotę za tym, co minione. Możemy powiedzieć, że najnowsza kultura popularna „przepisuje” historię, tworząc swoisty bank wspomnień kulturowych pokolenia dorastającego w epoce analogowej. W nurt ten wpisuje się serial Stranger Things, w którym odnajdujemy liczne aluzje literackie i kulturowe, a popularne wyobrażenia lat 80. (a w czwartym sezonie, zgodnie z zapowiedziami, lat 90.) powracają w postaci znanych klisz, fabul, motywów.

W epoce cyfrowej zmieniła się także forma dystrybucji, co potwierdza gwałtowny wzrost popularności telewizji internetowej (Netflix, HBO Go itp.). Nowoczesne medium przyspieszyło rewolucję w obrębie gatunku, jakim jest serial telewizyjny. W walce o widza zmienił się sposób prezentacji losów protagonistów, ograniczono powtarzalne struktury fabularne typowe dla oper mydlanych. Pojawił się nowy paradygmat opowiadania telewizyjnego, który 
już kilkanaście lat temu Jason Mittell (2006) określił mianem „złożonej narracyjności” [narrative complexity]. Serial stał się gatunkiem o wiele bardziej zróżnicowanym niż wcześniej, a do głównej osi narracyjnej znacznie częściej wplata się wątki charakterystyczne dla kryminału, horroru czy science fiction, nawet jeśli dany program nie reprezentuje stricte którejś z tych odmian gatunkowych (Borowiecki, 2020, s. 12). Zmieniły się również kreacje bohaterów, w których szczególny nacisk położono na rys psychologiczny. Zaczęto coraz śmielej odchodzić od zamkniętej struktury opowieści, a w zakończeniu poszczególnych sezonów twórcy częściej niż w XX wieku posługują się cliffhangerami, polegającymi na nagłym zawieszeniu akcji, co oczywiście ma na celu utrzymanie zainteresowania widzów fabułą. Nie dziwi zatem fakt, że współczesne seriale (zarówno dla dorosłych, jak i młodzieży) różnią się od produkcji powstałych w poprzednich dekadach. Modyfikacje w obrębie gatunku nasuwają skojarzenia z powieścią postmodernistyczną, w której oprócz zaburzonej linearności opowiadania - pojawiają się liczne odniesienia do innych tekstów kultury. Seriale stały się gatunkiem intertekstualnym, co potwierdza m.in. Stranger Things.

Rozważania na temat produkcji braci Dufferów wypada zacząć od refleksji natury genologicznej. Stranger Things - oprócz oczywistych związków $\mathrm{z}$ horrorem czy science fiction - nasuwa skojarzenia z teen drama, będącym według Rachel Moseley (2001, s. 41-43) typowo amerykańską odmianą gatunkową, w której pojawiają się stereotypowi bohaterowie, np. cheerleaderka, mięśniak, królowa mody, nerd, kujon czy buntownik. Protagonistami są głównie nastolatkowie, dorośli zaś występują w roli rodziców, opiekunów, nauczycieli, choć na marginesie warto podkreślić, że istnieją seriale adresowane do młodzieży, w których głównymi bohaterami są osoby dorosłe (Czarodziejki - Burge, 1998-2006; Anioł ciemności - Whedon, Greenwalt, 1998-2004). Z kolei dla Glyna Davisa i Kay Dickinson (2004, s. 2) kluczowym wyznacznikiem gatunkowym tej odmiany serialu jest widz. Teen dramas adresowane są w głównej mierze do nastoletniej widowni, dlatego też wydarzenia prezentowane są z perspektywy dorastającej młodzieży, a akcja najczęściej rozgrywa się w środowisku szkolnym i w przestrzeni domu, gdzie często organizowane są imprezy dla najbliższych przyjaciół. Ta odmiana serialu ma wiele cech wspólnych z popularną telenowelą (m.in. sposób prowadzenia narracji czy prezentowania środowiska, powielanie stereotypowych schematów fabularnych). Tematyka takich produkcji koncentruje się na problemach, z jakimi boryka się młodzież, takich jak dorastanie, nieszczęśliwa miłość, samotność, odrzucenie przez społeczność szkolną. Od początku XXI wieku produkcje reprezentujące tę odmianę gatunkową poruszają kwestie wcześniej zaliczane 
do tematów tabu ${ }^{1}$, czyli uzależnienie od alkoholu i narkotyków, orientacja psychoseksualna itd. Zmienia się także narracja prezentowanych zdarzeń twórcy odchodzą od wykorzystywanych do tej pory szablonów (Pięczka, Kuniczuk-Trzcinowicz, 2006, s. 369-375). Dzisiaj teen drama przypomina raczej twór hybrydyczny, łączący (jeśli odnieść tę kwestię do kategorii literaturoznawczych) narrację typową dla opowieści realistycznej z - jak wspomniano wcześniej - elementami kryminału, horroru, science fiction.

Drugą odmianą gatunkową, w którą wpisuje się Stranger Things, jest buddy movie, opowiadający o grupie przyjaciół przeżywających wspólnie liczne przygody. Każdy z nich cechuje się inną osobowością, łączy ich przyjaźń, szacunek oraz gotowość niesienia sobie wzajemnie pomocy w tarapatach (Millard, 2007). Ten typ produkcji wywodzi się z XIX-wiecznej literatury amerykańskiej - mam tu na myśli twórczość Marka Twaina i jego kreacje nastoletnich bohaterów w Przygodach Tomka Sawyera (1876/2019) oraz Przygodach Hucka Finna (1884/2019). Buddy movie ewoluował na przestrzeni stulecia, a perypetie bohaterów przedstawiane były m.in. w konwencji komediowej (lata 60. XX wie$\mathrm{ku}$ ) oraz sensacyjnej (lata 80. XX wieku). Relacje damsko-męskie, inaczej niż $\mathrm{w}$ komediach romantycznych, pełnią tutaj funkcję podrzędną. Buddy movie

1 Przywołajmy choćby serial Trzynaście powodów (Yorkey, 2017-2020), powstały na podstawie powieści Jaya Ashera (2007/2009) pod tym samym tytułem (Szmidt, 2017). Główna bohaterka (w tej roli Katherine Langford) przed popełnieniem samobójstwa nagrywa siedem kaset magnetofonowych, na których przedstawia powody tej dramatycznej decyzji. Każda strona nagrania (będąca tematem odrębnego epizodu) opowiada oddzielną historię dziewczyny powiązaną z jednym z protagonistów. Niewątpliwie interesujący w serialu jest psychologiczny portret bohaterki borykającej się z kolejnymi upokorzeniami ze strony rówieśników, przeżywającej rozczarowania, cierpiącej na pogłębiającą się depresję. Relacje Hannah z nastolatkami, nota bene stanowiące kalkę z powieści Carrie (King, 1974/2017), ukazują dramat osamotnionej dziewczyny. Poruszony w serialu kontrowersyjny temat samobójstwa wśród młodzieży okazuje się niezwykle aktualny w pierwszych dekadach XXI wieku, gdy wielu nastolatków boryka się z samotnością, cierpi na depresję, doświadcza wewnętrznej pustki (Kyzioł, 2019, s. 82-84). Drugim serialem, o którym warto wspomnieć, jest Riverdale (Aguirre-Sacasa, 2017- ). Jego fabuła nawiązuje do kultowego Miasteczka Twin Peaks (Frost, Lynch, 1990-1991). W prowincjonalnej amerykańskiej miejscowości ginie Jason Blossom (Trevor Stines), a jego szkolni rówieśnicy pragną rozwikłać tajemnicę i odkryć, kto stoi za śmiercią kolegi. Z pozoru nudne tytułowe Riverdale skrywa mroczne sekrety. Atmosferę niepewności, grozy potęgują także mgliste, oniryczne pejzaże. Trudno jednoznacznie określić czas akcji serialu. Z jednej strony, wystrój lokalnego baru oraz marki samochodów sugerują lata 50. Z drugiej zaś - bohaterowie posługują się smartfonami. W obu wymienionych produkcjach pojawiają się pojedyncze artefakty z epoki analogowej, pełniące wyłącznie marginalną funkcję (z wyjątkiem kaset magnetofonowych z Trzynastu powodów). 
koresponduje również z Kinem Nowej Przygody (Szyłak, Konefał, Kaczor, 2012), czerpiącym z gatunków popularnych i rozrywkowych, często łączącym elementy różnych konwencji (film sensacyjny, popularnonaukowy, fantasy, katastroficzny). O jego atrakcyjności świadczą liczne zwroty akcji, wartkie tempo, raptowne zaskoczenia oraz wyjątkowe zbiegi okoliczności (s. 6). Popularność tej odmiany gatunkowej wynika m.in. z nostalgii widzów, tęskniących za prostymi konstrukcjami fabularno-przygodowymi obecnymi w kulturze masowej. Niewątpliwie do klasyki buddy movies należy Goonies w reżyserii Richarda Donnera (1985), którego główni bohaterowie tworzą zgraną paczkę przyjaciół z osiedla. Bracia Dufferowie niemalże kopiują pojawiające się w tym filmie sceny, jak choćby wieczorną przejażdżkę rowerową nastolatków po opustoszałych ulicach miasteczka. W obu produkcjach protagoniści starają się rozwiązać tajemniczą zagadkę, a podejmowana przez nich misja ma na celu ocalenie lokalnej społeczności (w Goonies chodzi o zdobycie pieniędzy, które mają zablokować przebudowę osiedla na nowoczesne pole golfowe - w Stranger Things o pokonanie łupieżcy umysłów zagrażającego mieszkańcom Hawkins). Nie dziwi zatem fakt, że bracia Dufferowie dostrzegli potencjał tkwiący w latach 80., dekadzie obfitującej w kultowe buddy movies autorstwa Stevena Spielberga, George'a Lucasa czy Wesa Cravena.

Serial Stranger Things zachwycił krytyków filmowych, którzy podkreślali, że twórcom udało się odtworzyć realia lat 80. poprzez umiejętne połączenie różnych gatunków filmowych i telewizyjnych, począwszy od horroru czy science fiction po komedię i opowieść przygodową z elementami kryminału (Jakubowiak, 2017; Mróz, 2019; Socha, 2017). Widzowie zaś, jak pisze w recenzji Jakub Socha (2020), otrzymali „nostalgiczną pastylkę składającą się z popkulturowych artefaktów lat 80.”. Dla osób, które nie dorastały w tamtych czasach, program stanowi cenne źródło informacji na temat stylu życia ówczesnych nastolatków; dla starszej generacji oglądanie serialu podszyte jest nostalgią za utraconym okresem adolescencji. Wydaje się, że braciom Dufferom bliska jest postmodernistyczna koncepcja traktująca utwór jako punkt odniesienia do innych tekstów kultury, takich jak piosenki, komiksy, filmy, gry (Kostecka, Mik, Skowera, 2018, s. 16-17). Twórcy Stranger Things nie tylko zacierają granicę między kulturą "wysoką" a popularną, ale przede wszystkim eksponują wpływ tej drugiej na codzienną egzystencję - choćby poprzez ukazanie, jak popularne teksty kultury i wzorce narracyjne oddziałują na wybory bohaterów i wskazują im sposób postępowania, a wręcz stanowią instruktaż działania w konkretnych sytuacjach. W niniejszym artykule interesować mnie będą przede wszystkim obecne w dziele braci Dufferów intertekstualne nawiązania do tekstów popkultury $\mathrm{z}$ lat 80 . 
Dla twórców serialu istotnym punktem odniesienia stała się twórczość Stephena Kinga. Grupa nastoletnich przyjaciół ze Stranger Things przypomina protagonistów z kultowej powieści To (King, 1986/2019). Zarówno u jej autora, jak i u braci Dufferów przyjaciele tworzą paczkę - łączą ich wspólne zainteresowania, razem spędzają wolny czas, a także próbują rozwikłać tajemnicze (niekiedy irracjonalne) zagadki. Will Byers (Noah Schnapp), podobnie jak Benjamin Handscom z utworu Kinga, to samotnik, introwertyk, który unika kontaktu z rówieśnikami. Dobrze czuje się wyłącznie w towarzystwie bliskich przyjaciół, z którymi spędza wolny czas, grając w RPG. Dustin Henderson (Gaten Matarazzo) stanowi kalkę Richarda Toziera, mola książkowego potrafiącego przeczytać opasłe tomy w celu znalezienia upragnionej informacji. To genialny wynalazca i technik. Obaj wyróżniają się nieposkromionym gadulstwem, dzięki ekstrawertycznej naturze umiejętnie integrują grupę. Lucas Sinclair (Caleb McLaughin) to odpowiednik Michaela Hanlona, jedyny racjonalista w grupie, który dzięki umiejętnościom analitycznym potrafi przewidzieć skutki gwałtownie podjętych działań. Bohaterowie, jako reprezentanci osób popularnie określanych mianem nerdów, uczęszczają na kółko zainteresowań z fizyki, na którym pod kierunkiem nauczyciela pasjonata pracują nad kolejnymi wynalazkami. W drugim sezonie Stranger Things do paczki przyjaciół dołącza dziewczyna, Maxine „Max” Mayfield (Sadie Sink), będąca ofiarą przemocy domowej, podobnie jak Beverly Marsh z To. Jej oprawcą staje się starszy brat, Billy (Dacre Montgomery). Nawiasem mówiąc, jego styl ubierania się i fryzura nasuwają skojarzenia z członkami rockowych zespołów z lat 80 . (Guns N’ Roses, Bon Jovi czy Scorpions). Warto również wspomnieć o najnowszej, dwuczęściowej ekranizacji powieści Kinga z 2017 i 2019 roku w reżyserii Andy'ego Muschiettiego, gdzie w młodego Richiego Toziera wcielił się Finn Wolfhard, odtwórca roli Mike’a ze Stranger Things. Twórca drugiej adaptacji ${ }^{2}$ utworu mistrza grozy dokonał modyfikacji fabuły, również osadzając akcję części pierwszej i retrospekcji z części drugiej w latach 80., czasach, których symbolami stały się magnetowid, walkman czy rower BMX. Muschiettiemu udało się połączyć nowoczesny horror z pogłębioną charakterystyką psychologiczną bohaterów oraz narracją typową dla kryminału. Dominująca stylistyka tamtej dekady obecna jest również w obu filmach na płaszczyźnie dźwiękowej: śledząc losy bohaterów, usłyszymy utwory zespołów The Cure oraz New Kids

2 Pierwsza ekranizacja powieści Kinga w reżyserii Tommy’ego Lee Wallace’a miała premierę w 1990 roku i była dwuodcinkowym serialem grozy powstałym na fali popularności Miasteczka Twin Peaks oraz Opowieści z krypty (Gaines, Dodd, 1989-1996). Jego akcja rozgrywa się w latach 60. i 90., a twórcy ograniczyli wątek dorosłego życia bohaterów. 
on the Block. Uważny widz dostrzeże także afisze reklamujące kultowy horror Koszmar z ulicy Wiązów (Craven, 1984). Na marginesie mówiąc, twórcy Stranger Things nawiązują również do filmu Stań przy mnie w reżyserii Roba Reinera (1986; jest to adaptacja opowiadania Ciało ze zbioru Cztery pory roku Kinga, 1982/2002), które to dzieło również wpisuje się w konwencję buddy movie.

W pierwszym sezonie serialu braci Dufferów pojawia się tajemnicza Jedenastka (Millie Bobby Brown), przypominająca protagonistkę powieści Carrie, również autorstwa Kinga (1974/2017). Podobnie jak jej pierwowzór, bohaterka Stranger Things posiada nadprzyrodzone umiejętności telekinetyczne - potrafi nie tylko przesuwać przedmioty za pomocą myśli, lecz także częściowo kontrolować umysły innych osób. Obie dziewczyny to outsiderki. Wychowywana przez samotną matkę, fanatyczkę religijną, Carrie była idealnym obiektem żartów dla innych uczniów. Z kolei Jedenastka stała się ofiarą cynicznych naukowców, wykorzystujących jej nietypowe umiejętności do pracy nad bliżej nieokreśloną bronią. Bohaterka uciekła $\mathrm{z}$ tajemniczego laboratorium w Hawkins, gdzie była tzw. królikiem doświadczalnym. Warto podkreślić, że Nastka odgrywa kluczową rolę w serialu, gdyż to dzięki jej parapsychicznym mocom do ludzkiego świata przenika Demogorgon. Jak zauważa Mikołaj Marcela (2018, s. 263), na początku pierwszego sezonu dziewczyna przypomina istotę androgyniczą, gdyż jej wygląd (ogolona głowa) nie zdradza płci. Przez mieszkańców Hawkins postrzegana jest jako tajemniczy chłopiec, jej stylizacja zaś nasuwa skojarzenia z tytułowym bohaterem filmu E.T. Spielberga (1982; pisze o tym Marcela, 2018, s. 263). Bohaterka to obcy, przybyły - na poziomie symbolicznym - $\mathrm{z}$ innego wymiaru. Jest „podwójnie inna” [double other], ponieważ „jako kobieta walczy z tym, co jest złem dla mężczyzn" (Melzer, 2006, s. 117; cyt. za: Marcela, 2018, s. 264). Z jednej strony, w oczach pracowników tajemniczego laboratorium stanowi zagrożenie dla ludzkości. Z drugiej zaś - tylko ona może uratować świat przed destrukcją (również s. 264).

Zarówno King, jak i bracia Dufferowie osadzają akcję utworów w amerykańskim miasteczku położonym z dala od wielkich metropolii. Derry (To) oraz Hawkins (Stranger Things) jawią się jako nudna prowincja, gdzie egzystencja koncentruje się wyłącznie na powtarzaniu rutynowych czynności dnia codziennego. Sceneria w powieści Kinga pozwala na wyeksponowanie m.in. problemów rasizmu oraz przemocy domowej i rówieśniczej, której doświadczają protagoniści. Wizerunki rodzin odbiegają od tych utrwalonych chociażby $\mathrm{w}$ tradycji patriarchalnej. Beverly boryka się z sadystycznym ojcem, niejednokrotnie stosującym przemoc fizyczną oraz psychiczną wobec córki. Eddie Kaspbrak uzależniony jest od matki hipochondryczki, traktującej astmę syna jako śmiertelną chorobę. W Stranger Things również pojawiają się rozbite rodziny. 
Will Byers mieszka $\mathrm{z}$ bratem (Charlie Heaton) oraz mamą (Winona Ryder), postrzeganą przez mieszkańców jako znerwicowana, ekscentryczna, a niekiedy szalona kobieta. W niepełnej rodzinie dorasta także Dustin Henderson. Miejscem, w którym spotykają się wszyscy bohaterowie, jest dom Mike’a Wheelera. Jego rodzice z kolei nie ingerują zbytnio w życie swoich dzieci.

Nieprzypadkowo narracja w Stranger Things prowadzona jest z perspektywy głównych bohaterów. Zabieg ten ma na celu wyeksponowanie innego niż dominujący sposobu postrzegania świata. Wydaje się, że twórcy serialu nawiązują do romantycznej koncepcji młodego protagonisty, postaci nieprzeciętnej, potrafiącej odczytywać tajemnicze znaki oraz odbierać zapowiedzi przyszłych zdarzeń (Kubale, 1984). W Stranger Things kluczową rolę odgrywa punkt widzenia młodzieży. Podkreślmy, że to nastoletni bohaterowie dostrzegają, iż do ich przyjaznego świata wkracza zło, z którym należy walczyć (serial powtarza więc rozwiązanie fabularne znane $z$ wielu utworów fantastycznych; Skowera, 2018, s. 65). Ich z pozoru mało istotne zainteresowania (jak komiksy, gry planszowe) pełnią niezwykle ważną funkcję $\mathrm{w}$ walce $\mathrm{z}$ tajemniczymi siłami.

Popularne kino lat 80 . obfitowało w wizje podwójnej natury rzeczywistości czy też obrazy kontrempirycznych uniwersów - by wspomnieć wyprodukowanego przez Spielberga Ducha w reżyserii Tobe’a Hoopera (1982), Niekończąca się opowieść Wolfganga Petersena (1984) na podstawie powieści Michaela Endego (1979/2018), Labirynt Jima Hensona (1986). Również w serialu braci Dufferów dominuje dualistyczna wizja świata przedstawionego. Równolegle do realnego Hawkins funkcjonuje odrębna, alternatywna rzeczywistość. Podobnie jak w baśniach ludowych czy utworach typu fantasy istotne znaczenie mają w Stranger Things miejsca graniczne, pozwalające na przejście do innego wymiaru. Jak dowodzi Krzysztof M. Maj (2015, s. 55), taka konstrukcja świata przedstawionego zakłada:

[...] konfrontację dwóch nierównoważnych niewspółmożliwych porządków: empirycznego Tu (przestrzeni paradygmatycznej, wyjściowej, własnej, zapoznanej i oswojonej) oraz kontremiprycznego Tam (przestrzeni wyobcowanej, wykluczonej, wyizolowanej, wyodrębionej, niepoznanej, obcej).

Choć portali między światami jest $\mathrm{w}$ serialu wiele, to $\mathrm{w}$ pierwszym sezonie, na poziomie symbolicznym, sferą przejścia jest przede wszystkim las, będący przestrzenią graniczną, transgraniczną, zakorzenioną w świadomości ludzkiej (Slany, 2016, s. 275). Przypomnijmy, że sezon ten rozpoczyna się od zaginięcia Willa Byersa właśnie w lesie. Chłopiec, próbując skryć się przed monstrum w szopie nieopodal domu, trafia do alternatywnego świata, przypominającego 
rzeczywistość z horrorów i utworów science fiction z lat 80., np. ze wspomnianego już Ducha (Kostyra, 2020, s. 35-60). Dominujące kolory - czerń oraz czerwień - mają za zadanie potęgować uczucie przerażenia u odbiorcy. Przestrzeń ma labiryntowy charakter, co dodatkowo wywołuje wrażenie osaczenia. Grozę ewokują także opustoszałe ruiny budynków oraz tajemnicze drapieżne stworzenie polujące na kolejne ofiary. Na skutek pęknięcia granicy między światami krwiożercza istota przedostaje się do realnego Hawkins, a wraz z nim do świata faktycznego przenika pierwiastek niesamowitości. W Stranger Things nakładają się na siebie dwie makiety miasta - realnego oraz kontrempirycznego, przesyconego grozą. Znamienne jest, że dualizm ten dostrzegają wyłącznie nastoletni protagoniści oraz dwie dorosłe osoby: Joyce Byers (matka zaginionego chłopca) oraz Jim Hopper (komendant miejscowej policji; w tej roli David Harbour). Co więcej, tylko kobiety - Jedenastka, Joyce, Nancy Wheeler (siostra Mike’a, grana przez Natalię Dyer) - oraz Hopper mogą przeniknąć do alternatywnej rzeczywistości i powrócić (Marcela, 2018, s. 272). Być może umiejętność ta wynika z ich odmiennej (w stosunku do pozostałych mieszkańców Hawkins) optyki postrzegania świata.

W pierwszym sezonie bohaterowie walczą z przybywającym z Drugiej Strony Demogorgonem, który nota bene pojawił się w Hawkins za sprawą Nastki. Postać monstrum została scharakteryzowana w towarzyszącej ich ulubionej grze Księdze potworów [Monster Manual] i to właśnie w niej protagoniści poszukują informacji na temat skutecznej metody pokonania antagonisty. Jak zauważa Marcela (2018, s. 261), nazwa stworzenia nie jest przypadkowa - należy ono do niesamowitych i niejednoznacznych istot mitycznych. Pisał o nim w Genealogia deorum gentilium [Genealogia bogów] Giovanni Boccaccio (1472/2002), w Raju utraconym John Milton (1674/2011), w Prometeuszu wyzwolonym Percy Bysshe Shelley (1820/1982). Demogorgon to „bóstwo” chaosu zagrażające porządkowi panującemu w Hawkins. Przypomina tytułowe monstrum z Obcego - ósmego pasażera Nostromo w reżyserii Ridleya Scotta (1979). Początkowo w wizjach Willa jego kształt nasuwa skojarzenia z gigantycznym pająkiem, którego odnóża oplatają całe miasto. Podobnie jak w Obcym... istota przeobraża się z poczwarki w przerażającego potwora o długich, lepkich mackach, co potęguje u widza uczucie przerażenia oraz wstrętu. Sceny ataku stanowią kalkę z filmu Scotta - nawiązują do fragmentu, w którym główna bohaterka, Ripley (Sigourney Weaver), czuje oddech zbliżającego do niej monstrum. Łupieżca umysłu przypomina także pojawiającego się w snach dzieci Freddy'ego Krugera z Koszmaru z ulicy Wiązów. W trzecim sezonie Stranger Things dowiadujemy się, że potwór przenika również do umysłów swoich potencjalnych ofiar. Atakuje niczym wirus, gromadząc armię do przejęcia władzy 
nad światem. Jedynym możliwym sposobem pokonania wroga jest zlokalizowanie organizmu-żywiciela, sterującego podporządkowanymi mu istotami. Walka $\mathrm{z}$ łupieżcą umysłu pochłaniającym kolejne ofiary tym razem nasuwa skojarzenia z filmem Dzień żywych trupów w reżyserii George’a Romera (1985), gdzie zombie opanowują niemalże całe miasto, a grupa ocalałych pracuje nad skuteczną bronią mającą zlikwidować wroga ludzkości.

Drugim źródłem zagrożenia jest tajemnicze laboratorium mieszczące się na obrzeżach miasteczka. Tak naprawdę nikt nie wie, nad czym pracują naukowcy w pilnie strzeżonym ośrodku. Instytut ten odzwierciedla patriarchalny porządek społeczeństwa, zgodnie z którym wszystkie istoty oraz osoby odbiegające od obowiązujących wzorców normatywnych stanowią zagrożenie dla otoczenia. To tutaj pracują głównie mężczyźni przeprowadzający testy oraz doświadczenia na dzieciach uznanych za zaginione. W retrospekcjach w pierwszym sezonie poznajemy relacje łączące Nastkę z opiekunem, nazywanym przez bohaterkę „papą” (Matthew Modine). Nie przypomina on wzorowego ojca, jest niezwykle mściwy i apodyktyczny. Po ucieczce Jedenastki rusza za nią w pościg, a towarzyszy mu grupa wyszkolonych pracowników rządowych, potrafiących bez skrupułów zabić postronne osoby, które miałyby choć śladowe informacje na temat przeprowadzanych w laboratorium eksperymentów. Wątek ten koresponduje z sytuacją społeczno-polityczną Stanów Zjednoczonych w latach 80.; ogólnospołeczną histerię dotyczącą wszechobecnego wywiadu potęgowały doniesienia o niejawnych agencjach związanych z CIA, których praktyki i cele znane były niewielu osobom (Andrzejczak, 2012, s. 182). Nieufność wobec władzy i szukanie kolejnych spisków potęgowały uczucie niepokoju, czemu towarzyszyła pesymistyczna ocena neokonserwatywnego rządu Ronalda Reagana. Problem ten został również wyeksponowany w trzecim sezonie serialu, kiedy to Dustin przypadkowo przechwytuje radziecki przekaz i wraz z przyjaciółmi pracującymi w lodziarni rozpoczyna śledztwo. Okazuje się, że w podziemiach nowo powstałego centrum handlowego Starcourt w Hawkins przebywają komuniści, pracujący nad nowoczesną bronią.

Oprócz czytelnych inspiracji twórczością Kinga i Scotta warto przywołać także inne dzieła popkultury z lat 80., do których odwołują się bracia Dufferowie. I tak scena $\mathrm{z}$ pierwszego sezonu, kiedy bohaterowie uciekają przed wrogiem z pomocą Jedenastki (wykorzystującej swoje telepatyczne umiejętności, aby ocalić grupę), stanowi kalkę sceny z filmu E.T., ukazującej Elliotta (Henry Thomas) w czasie podniebnej przejażdżki rowerem $\mathrm{z}$ kosmicznym przyjacielem. Przed Halloween protagoniści przebierają się zaś w charakterystyczne stroje rodem z komedii grozy Pogromcy duchów (Reitman, 1984), a każdy z nich reprezentuje określonego bohatera z filmu. Nota bene dochodzi między nimi 
do kłótni, gdyż w pierwowzorze występuje tylko trzech naukowców walczących z masowym atakiem duchów na nowojorską metropolię, a chłopców jest czterech. W scenerii prowincjonalnego miasteczka pojawia się także radziecki szpieg, przypominający wyglądem oraz zachowaniem Arnolda Schwarzeneggera z Terminatora w reżyserii Jamesa Camerona (1984). Mężczyzna przybywa do Hawkins, aby unicestwić wszelkich oponentów sowietów. Podąża on tropem policjanta Hoppera oraz towarzyszącej mu Joyce.

Niezwykle ważną funkcję w hermetycznym świecie protagonistów pełni również gra planszowa Dungeons and Dragons (Gygax, Arneson, 1974), uznawana za prekursorkę nowoczesnych RPG-ów. Warto podkreślić, że w latach 80. gra ta była bardzo popularna w USA, a nawet włączano ją do ogólnej dyskusji, jako że środowiska konserwatywne powiązały ją z satanizmem. Jej gracze wcielają się w fikcyjne postaci, biorące udział w wyimaginowanych przygodach w scenerii typowej dla fantasy. Podczas gry bohaterowie tworzą drużyny, wspólnie poszukują rozwiązania problemów, biorą udział w bitwach oraz zdobywają skarby i wiedzę. Pierwszy sezon serialu rozpoczyna się i kończy sceną, w której chłopcy grają w Dungeons and Dragons. Istotną rolę odgrywa także wspomniany już podręcznik do tej gry, zawierający niezbędne informacje oraz reguły, których należy przestrzegać (Player's Handbook). W drugim sezonie bohaterowie wkraczają zaś w świat salonowych gier pikselowych i odkrywają, że najlepiej z nich radzi sobie nowa koleżanka, Max.

W serialu braci Dufferów duże znaczenie ma także wyselekcjonowana muzyka z minionej dekady. W pierwszym sezonie Jonathan Byers, wspominając zaginionego brata, słucha ich ulubionej piosenki Should I Stay or Should I Go zespołu The Clash (1982). Zarówno w pierwszym, jak i w trzecim sezonie pojawia się utwór Heroes ikony lat 80. - Davida Bowiego (1977). Podczas szkolnego balu w finałowym odcinku drugiego sezonu bohaterowie tańczą ze swoimi sympatiami, słuchając Time After Time Cyndi Lauper (1984) oraz Every Breath You Take The Police (1983), utworów zaliczanych do klasyki ballad.

W epizodzie trzeciego sezonu, w którym Jedenastka i Max udają się do centrum handlowego na zakupy, nie mogło zabraknąć w tle utworu Material Girl Madonny (1984). Wybór piosenki nie jest przypadkowy, gdyż na początku lat 80. Stany Zjednoczone wkroczyły w okres stabilizacji oraz dobrobytu. Powstające wówczas liczne galerie handlowe zmieniły styl życia Amerykanów, którzy pogrążali się w masowej konsumpcji. Miejsca te przyciągały dzieci oraz młodzież, coraz chętniej spędzających wolny czas na pasażach handlowych. Nieprzypadkowo w trzecim sezonie akcja toczy się głównie w Starcourt, nowo otwartej galerii. Braciom Dufferom udało się skomentować wciąż zyskujące na sile zjawisko globalizacji, kiedy to świat zaczął przypominać „hipermarket 
kulturowy" (Paleczny, 2008, s. 106), z powszechną, nieograniczoną dostępnością do jego wytworów. Rzeczywistość stała się przestrzenią przesiąkniętą kulturą instant, „w której wszystko jest ujednolicone i nastawione na łatwą przyjemność" (Trześniewska, 2013, s. 60). Wzrastająca liczba sieci handlowych, fast foodów oraz popularnych marek samochodowych przyczyniła się do powstania nowej rzeczywistości, przypominającej „globalną wioskę”, w której zaczęły zacierać się bariery językowe, religijne, rasowe (Paleczny, 2008, s. 134). „Postępująca macdonaldyzacja społeczeństwa spowodowała rutynizację ludzkich zachowań skoncentrowanych na triadzie: doświadczenie-przyjemność-szybkość" (Trześniewska, 2013, s. 60). Preludium do ostatecznego starcia z radzieckimi szpiegami w centrum handlowym stanowi natomiast wykonanie przez Dustina i Suzie utworu Neverending Story Limahla (1984), pochodzącego ze ścieżki dźwiękowej do kultowego wśród miłośników fantasy, wspomnianego już filmu Niekończąca się opowieść Petersena.

Ze względu na liczne odniesienia do innych tekstów popkultury z lat 80 . trudno określić jednoznacznie, jaką odmianę gatunkową reprezentuje Stranger Things. Z jednej strony przedstawiony świat - widziany z perspektywy młodzieży, ukazujący chwile spędzone w szkole, $\mathrm{w}$ domu, podczas zabawy z rówieśnikami - sugeruje, że mamy do czynienia z teen drama bądź buddy movie. To interesujące świadectwo tego, jak w drugiej dekadzie XXI wieku wygląda wyobrażenie o młodych ludziach dorastających w świecie bez telefonów komórkowych oraz komputerów. Wprowadzenie wątku fantastycznego, jakim jest alternatywna, mroczna rzeczywistość zagrażająca porządkowi panującemu w Hawkins, budzi skojarzenia z poetyką grozy. Z kolei śledztwo prowadzone przez bohaterów w pierwszym i trzecim sezonie nasuwa asocjacje z kryminałem, gatunkiem popularnym na całym świecie, zarówno wśród czytelników, jak i widzów (Czapliński, 2014).

Adriana Prodeus (2019) zwróciła uwagę na transformację wizerunku geeków (entuzjastów komputerów i gier) oraz nerdów (skupionych na przyswajaniu wiedzy związanej z naukami ścisłymi) na przestrzeni ostatnich dwóch dekad. U schyłku XX wieku byli oni ciągle postrzegani jako outsiderzy, dziwacy, których styl życia, diametralnie odmienny od tego prowadzonego przez rówieśników, stanowił strategię obronną przetrwania w szkole. Dzisiaj terminy "geek” oraz „nerd” nie mają już pejoratywnego wydźwięku. Bohaterowie Stranger Things udowadniają, że warto się uczyć, rozwijać swoje nietypowe zainteresowania, czytać książki, analizować skomplikowane zjawiska fizyczne, gdyż to dzięki własnemu rozwojowi stajemy się bardziej empatyczni, otwarci na drugiego człowieka. Co więcej, możemy podjąć próbę opisania świata, zrozumienia mechanizmów jego działania. 
Dla pokolenia współczesnych trzydziesto- i czterdziestolatków serial braci Dufferów stanowi rodzaj nostalgicznej podróży do lat młodości. Dodajmy, że to podróż opierająca się na popkulturowych wyobrażeniach lat 80. Przywoływane przedmioty, stanowiące dzisiaj martwe media, nie tylko budzą sentyment, lecz także przywołują wspomnienia związane z ich użytkowaniem. Bogata enumeracja retroobiektów, muzyka $z$ lat 80 ., liczne aluzje i odniesienia do kultowych filmów pojawiające się w Stranger Things mają głębszy wymiar niż tylko (pozornie) wierne odzwierciedlenie realiów tamtej dekady. Odgrywają one kluczową rolę w procesie mitologizacji własnej generacji (Napiórkowski, 2019, s. 220-221). Jeśli wziąć pod uwagę, że nasza pamięć jest migotliwa, fragmentaryczna i wybiórcza, przedmioty, zachowania czy doświadczenia utrwalone w serialu można rozumieć jako narzędzia służące porządkowaniu świata, nadawaniu mu sensownej struktury - to na ich podstawie możemy bowiem wyodrębnić tzw. pokolenia (s. 174).

W tytule serialu braci Dufferów pojawia się kluczowe słowo stranger, które możemy rozumieć dwojako. Po pierwsze - jako rzeczownik oznacza „obcego”, „nieznajomego", a w tym kontekście jest nim zarówno Jedenastka, jak i tajemnicze monstrum. Po drugie - jako przymiotnik w stopniu wyższym („dziwniejszy”) ma szerszy zakres semantyczny i wydaje się odnosić do konstrukcji świata przedstawionego. To ostatnie znaczenie jest mi bliższe, gdyż koresponduje ono $\mathrm{z}$ pesymistycznymi nastrojami dominującymi $\mathrm{w}$ ponowoczesnej rzeczywistości. Współczesny świat okazuje się bizarny, dziwaczny, trudny do zdefiniowania. Postęp technologiczny usprawnił naszą codzienną egzystencję, ale nie nadążamy za nowinkami technologicznymi, a każdego dnia zalewają nas fake newsy. Rzeczywistość jest bardziej skomplikowana, niż by nam się to wydawało. Z jednej strony, tęsknimy za opowieściami scalającymi nasz świat oraz kreującymi iluzję bycia podmiotem pewnej gry. Stąd też rosnąca popularność seriali (m.in. Wiedźmina - Schmidt Hissrich, 2019- ) oraz książek science fiction oraz fantasy (Koziołek, 2020, s. 44), zacierających granice między światem realnym a wyobrażonym. Z drugiej zaś, marzymy, aby w naszej rutynowej egzystencji pojawił się element niezwykłości, stanowiący impuls do głębszej zadumy, dzięki któremu, tak jak bohaterowie Stranger Things, odkryjemy inny, wcześniej niedostrzegalny wymiar rzeczywistości.

\section{Bibliografia}

Aguirre-Sacasa, R. (prod.). (2017- ). Riverdale [serial telewizyjny]. CW.

Andrzejczak, K. (2012). Opowieści literackiej Ameryki. Zarys prozy Stanów Zjednoczonych od początków do czasów najnowszych. TAiWPN Universitas. 
Asher, J. (2009). Trzynaście powodów (A. Górska, tłum.). Rebis. (wyd. oryg. 2007).

Boccaccio, G. (2002). Genealogia deorum gentilium: Manuscript, 1385-1387. University of Chicago. (wyd. oryg. 1472).

Borowiecki, A. (2020). Zmieniający się paradygmat opowiadania we współczesnych serialach grozy. Media - Kultura - Komunikacja Społeczna, 16(2), 11-20. https:// doi.org/10.31648/mkks.6286.

Bowie, D. (1977). Heroes [piosenka]. W: Heroes [album muzyczny]. RCA.

Burge, C. M. (prod.). (1998-2006). Charmed [Czarodziejki] [serial telewizyjny]. WB.

Cameron, J. (reż.). (1984). The terminator [Terminator] [film]. Columbia Pictures.

Craven, W. (reż.). (1984). A nightmare on Elm Street [Koszmar z ulicy Wiązów] [film]. New Line Cinema.

Czapliński, P. (2014). Po co pop. Książki. Magazyn do Czytania, 2(13), 42-45.

Davis, G., Dickinson, K. (2004). Teen TV: Genre, consumption, identity. British Film Institute.

Demme, J. (reż.). (1991). The silence of the lambs [Milczenie owiec] [film]. Orion Pictures.

Donner, R. (reż.). (1985). The Goonies [Goonies] [film]. Warner Bros. Pictures.

Duffer, M., Duffer, R. (prod.). (2016- ). Stranger things [serial telewizyjny]. Netflix.

Ende, M. (2018). Niekończąca się historia (R. Wojnakowski, tłum.). Znak. (wyd. oryg. 1979).

Frost, M., Lynch, D. (prod.). (1990-1991). Twin Peaks [Miasteczko Twin Peaks] [serial telewizyjny]. ABC.

Frost, M., Lynch, D. (prod.). (2017). Twin Peaks: Season 3 [Miasteczko Twin Peaks. Sezon trzeci] [serial telewizyjny]. Showtime.

Fuller, B. (prod.). (2013-2015). Hannibal [serial telewizyjny]. NBC.

Gaines, W., Dodd, S. (prod.). (1989-1996) Tales from the crypt [Opowieści z krypty] [serial telewizyjny]. HBO.

Garth, J., Spelling, T., Chessler, M., Alberghini, C. (prod.). (2019). BH90210 [serial telewizyjny]. Fox.

Gygax, G., Arneson, D. (1974). Dungeons and dragons. TSR.

Henson, J. (reż.). (1986). Labyrinth [Labirynt] [film]. Tri-Star Pictures.

Hooper, T. (reż.). (1982). Poltergeist [Duch] [film]. MGM.

Jakubowiak, M. (2017, 1). Słonecznik, powtórz, tęcza, pamiętaj. Dwutygodnik, 224. Pobrane 10 stycznia 2021 z: https://www.dwutygodnik.com/artykul/7466-slonecznik-powtorz-tecza-pamietaj.html.

King, S. (2017). Carrie (D. Górska, tłum.). Albatros. (wyd. oryg. 1974).

King, S. (2002). Cztery pory roku (Z. A. Królicki, tłum.). Albatros (wyd. oryg. 1982).

King, S. (2019). To (R. Lipski, tłum.). Albatros. (wyd. oryg. 1986). 
Kostecka, W., Mik, A., Skowera, M. (2018). Słowo wstępne. W: W. Kostecka, A. Mik, M. Skowera (red.), Łapacz snów. Studia o twórczości Neila Gaimana (s. 9-21). Wydawnictwo Naukowe i Edukacyjne SBP.

Kostyra, K. (2020). Uwaga, pułapki na dzieci! Topografia nawiedzonego domu w Duchu Stevena Spielberga i Tobe’a Hoopera. Dzieciństwo. Literatura i Kultura, 2(1), 35-60. https://doi.org/10.32798/dlk.518.

Koziołek, R. (2020). Magowie. Made in Poland. Ksiażki. Magazyn do Czytania, 1(40), $40-44$.

Kryńska, E. (2017). Ekonomiczny kontekst problemu społecznego - przypadek prekariatu. Problemy Polityki Społecznej, 26, 13-26.

Kubale, A. (1984). Dziecko romantyczne. Szkice o literaturze. Zakład Narodowy im. Ossolińskich, Wydawnictwo PAN.

Kyzioł, A. (2019). Dorosłe seriale dla nastolatków. Polityka, 28, 82-84.

Lauper, C. (1984). Time after time [piosenka]. W: She's so unusual [album muzyczny]. Epic.

Madonna. (1984). Material girl [piosenka]. W: Like a virgin [album muzyczny]. Sire, Warner Bros.

Maj, K. M. (2015). Allotopie. Topografia światów fikcjonalnych. TAiWPN Universitas.

Marcela, M. (2018). Stranger Things, czyli kobiety i potwory. Teksty Drugie, 5, 257-275.

Melzer, P. (2006). Alien constructions: Science fiction and feminist thought. University of Texas Press.

Millard, K. (2007). Coming of age in contemporary American fiction. Edinburgh University Press.

Milton, J. (2011). Raj utracony (M. Słomczyński, tłum.). Zielona Sowa. (wyd. oryg. 1674).

Mittell, J. (2006). Narrative complexity in contemporary American television. The Velvet Light Trap, 58, 29-40. https://doi.org/10.1353/vlt.2006.0032.

Limahl. (1984). Neverending story [piosenka]. W: The Neverending Story soundtrack [album muzyczny]. EMI Group Limited.

Moseley, R. (2001). The teen series. W: G. Creeber (red.), The television genre book (s. 41-43). British Film Institute.

Mróz, K. (2019, 5 lipca). Stranger Things 3 jest świetne. To młodzieżowa komedia grozy i zimnowojenny koszmar o „ruskich”. Gazeta Wyborcza. Pobrane 10 stycznia 2021 z: https://wyborcza.pl/7,90535,24966145,stranger-things-3-jest-swietne-to-mlodziezowa-komedia-grozy.html.

Muschietti, A. (reż.). (2017). It [To] [film]. Warner Bros. Pictures.

Muschietti, A. (reż.). (2019). It: Chapter Two [To. Rozdział 2] [film]. Warner Bros. Pictures.

Nacher, A. (2011). Remiks i mashup - o niełatwym współbrzmieniu dwóch cyberkulturowych metafor. Przegląd kulturoznawczy, 9(1), 77-89. 
Napiórkowski, M. (2019). Kod kapitalizmu. Jak Gwiezdne wojny, Coca Cola i Leo Messi kieruja twoim życiem. Wydawnictwo Krytyki Politycznej.

Paleczny, T. (2008). Socjologia tożsamości. Oficyna Wydawnicza AFM.

Patrick, S., Schwartz, J., Savage, S. (prod.). (2017- ). Dynasty [Dynastia] [serial telewizyjny]. The CW.

Petersen, W. (reż.). (1984). The neverending story [Niekończąca się opowieść] [film]. Warner Bros.

Pięczka, B., Kuniczuk-Trzcinowicz, A. (2006). Melodramat. W: T. Żabski (red.), Słownik literatury popularnej (s. 369-375, wyd. 2 popr. i rozsz.). Wydawnictwo UWr.

Prodeus, A. (2019, 13 lipca). Demontaż atrakcji: Stranger Things. Vogue. Pobrane 9 stycznia $2021 \mathrm{z}$ : https://www.vogue.pl/a/demontaz-atrakcji-stranger-things.

Reitman, I. (reż.). (1984). Ghostbusters [Pogromcy duchów] [film]. Columbia Pictures.

Reiner, R. (reż.). (1986). Stand by me [Stań przy mnie] [film]. Columbia Pictures.

Reynolds, S. (2018). Retromania. Jak popkultura żywi się własna przeszłością (F. Łobodziński, tłum.). Kosmos. (wyd. oryg. 2011).

Romero, G. A. (reż.). (1985). Day of the dead [Dzień żywych trupów] [film]. United Film Distribution.

Schmidt Hissrich, L. (prod.). (2019- ). The Witcher [Wiedźmin] [serial telewizyjny]. Netflix.

Scott, R. (reż.). (1979). Alien [Obcy - ósmy pasażer Nostromo] [film]. $20^{\text {th }}$ Century Fox. Shapiro, E., Shapiro, R. (prod.). (1981-1989). Dynasty [Dynastia] [serial telewizyjny]. ABC.

Shelley, P. B. (1982). Prometeusz wyzwolony (L. Elektorowicz, tłum.). Wydawnictwo Literackie. (wyd. oryg. 1820).

Skowera, M. (2018). Pamięć - dzieciństwo - literatura dziecięca. Wokół Oceanu na końcu drogi Neila Gaimana. W: W. Kostecka, A. Mik, M. Skowera (red.), Lapacz snów. Studia o twórczości Neila Gaimana (s. 53-77). Wydawnictwo Naukowe i Edukacyjne SBP.

Slany, K. (2016). Orbis exterior w baśni magicznej i jego symbolika w Oblubienicy Tygrysa i Towarzystwie wilków Angeli Carter. W: W. Kostecka, M. Skowera (red.), Geografia krain zmyślonych. Wokół kategorii miejsca i przestrzeni w literaturze dziecięcej, młodzieżowej i fantastycznej (s. 269-286). Wydawnictwo SBP.

Socha, J. (2017). Nugat dla potwora. Dwutygodnik, 223. Pobrane 10 stycznia 2021 z: https://www.dwutygodnik.com/artykul/7458-nugat-dla-potwora.html?print=1.

Spielberg, S. (reż.). (1982). E.T. the extra-terrestrial [E.T.] [film]. Universal Pictures.

Star, D. (prod.). (1990-2000). Beverly Hills, 90210 [serial telewizyjny]. Fox.

Szmidt, O. (2017, 18 maja). Dlaczego obejrzałam wszystkie odcinki Trzynastu powodów. Czas Kultury. Pobrane 30 grudnia 2020 z: http://czaskultury.pl/czytanki/ dlaczego-obejrzalam-wszystkie-odcinki-trzynastu-powodow/. 
Szyłak, J., Konefał, S. J., Kaczor, K. (2012). Kino Nowej Przygody. Słowo/Obraz Terytoria.

The Clash. (1982). Should I stay or should I go [piosenka]. W: Combat rock [album muzyczny]. Epic.

The Police. (1983). Every breath you take [piosenka]. W: Synchronicity [album muzyczny]. A\&M.

Trześniewska, A. (2013). Człowiek w sieci kultury instant. O powieści Dawida Kaina Za pięć rewolta. LiteRacje, 29(2), 59-63.

Wallace, T. L. (reż.). (1990). It [To] [serial telewizyjny]. ABC.

Whedon, J., Greenwalt, D. (prod.). (1998-2004). Angel [Anioł ciemności] [serial telewizyjny]. WB.

Yorkey, B. (prod.). (2017-2020) 13 reasons why [Trzynaście powodów] [serial telewizyjny]. Netflix. 